\title{
PERFORMANCE OF BROILERS FED DIETS SUPPLEMENTED WITH GRADED LEVELS OF SOYBEAN OIL AND DIFFERENT SOURCES OF BONE MEAL
}

\author{
Surya Prasad Tiwari ${ }^{1,2^{*}}$, Maheshwor Sapkota ${ }^{2}$, Dainik Bahadur Nepali ${ }^{3}$, Jagat Lal Yadav ${ }^{3}$ and \\ Geeta Jamarkattel Tiwari ${ }^{4}$ \\ ${ }^{1}$ Plant Developmental Biology and Plant Physiology Institute, University of Kiel, Germany \\ ${ }^{2}$ Institute of Agriculture and Animal Science, Tribhuvan University, Rampur, Chitwan, Nepal \\ ${ }^{3}$ Faculty of Animal Science, Veterinary Science and Fisheries, Agriculture and Forestry University, Rampur, Chitwan, Nepal \\ ${ }^{4}$ Saptagandaki Multiple Campus, Tribhuvan University, Bharatpur, Chitwan, Nepal \\ *Corresponding author’s email: stu115228@mail.uni-kiel.de / suryatiwarig@ gmail.com
}

\begin{abstract}
An experiment was conducted to investigate the effects of inclusion of three levels of soybean oil $(0 \%, 2 \%$ and $4 \%)$ and three sources of commercial bone meals (GBM, PBM and IBM) in the diet of broiler chicken. Body weight, weight gain, feed consumption, feed efficiency, digestibility coefficient, calcium, phosphorus and ash content of blood and bone of broilers were measured. Significantly higher $(\mathrm{P}<0.01)$ average weekly feed consumption, average cumulative body weight, average weekly body weight gain was found in broilers fed diets containing soybean oil. The highest $(5058.27 \mathrm{~g})$ average total feed consumption was recorded on $\mathrm{T}_{9}$ and the lowest $(4117.88 \mathrm{~g})$ on $\mathrm{T}_{1}$. The highest average cumulative body weight was obtained on $\mathrm{T}_{6}(2168.33 \mathrm{~g})$ and was the lowest on $\mathrm{T}_{1}(1930.00 \mathrm{~g})$. Similarly, the highest average body weight gain was recorded on $\mathrm{T}_{6}(301.04 \mathrm{~g})$ and the lowest on $\mathrm{T}_{1}(273.77 \mathrm{~g})$. The abdominal fat weight percentage was maximum $(2.38 \%)$ on the diet containing $4 \%$ soybean oil with GBM and minimum (1.04\%) on the diet without soybean oil with IBM. However, the overall performance of broilers was found improved on the diet containing soybean oil. The ash, calcium and phosphorus content of blood and bone were better when supplied the diet with $2 \%$ to $4 \%$ soybean oil containing the sources of bone meal. Considering better bone calcification, phosphorus and minerals utilization in the chicken body, $2 \%$ to $4 \%$ levels of the soybean oil with the GBM source of bone meal could be incorporated in the diets.
\end{abstract}

Keywords: Soybean meal; Bone meal; Broilers; Performance)

Abbreviations: $\mathrm{GBM}=\mathrm{G}$ bone meal source, $\mathrm{PBM}=\mathrm{P}$ bone meal source, $\mathrm{IBM}=\mathrm{I}$ bone meal source

\section{Introduction}

Poultry production in Nepal has been flourishing in providing meat and egg as a good source of protein in the diet of people. Proper nutrition is essential in maintaining the health of poultry birds. The essential mineral elements and lipids perform many useful functions in the chicken body. Minerals give rigidity and strength to their skeleton and are the major constituents. The two minerals calcium and phosphorus comprises more than $70 \%$ of the mineral content of the animal body. Calcium is the most prevalent mineral in the body and is required in the diet in larger quantities than any other mineral (Klasing, 1998) Bone formation is highly dependent on the dietary concentrations of calcium and phosphorus as well as on the intake of vitamin D (NRC, 1984) Bone meal supplies most of the minerals such as calcium, phosphorus etc which are very crucial for the formation and maintenance of the skeleton. Because of many interactions of calcium and phosphorus, the two elements are usually considered together. In case of young birds-fed a special fattening diet, much of the increase in body weight is due to the growth of various tissues, but there is also a considerable amount of deposition of fat, if a good fattening diet is used. A good raw material could be a tool to increase economic efficiency in the process of fattening, but also to improve the protein and fat content in chicken meat. The addition of fat to diets, besides supplying energy, improves the absorption of fat-soluble vitamins, diminishes the pulverulence, increases the palatability of the rations, and increases the efficiency of the consumed energy (lower caloric increment). Furthermore, it reduces the passage rate of the digesta in the gastrointestinal tract, which allows a better absorption of all nutrients present in the diet.

Bone formation, digestibility of minerals and amino acids are highly dependent on the dietary concentrations of calcium and phosphorus as well as on adequate intake of 
vitamin D. Poor growth may also be a sign of calcium and phosphorus deficiency. Dietary excesses of both calcium and phosphorus should be avoided since the intestinal absorption of the other mineral elements may be hindered. The sternum and rib bones are frequently deformed and all bones are easily broken. The dietary management to prevent this condition is very essential.

Fats and oils are the most concentrated forms of stored energy in animal kingdom as plants store most of their energy in the form of carbohydrates primarily as starch. It furnishes 2.5 times more as many calories as do carbohydrates and proteins. It provides insulation for the vital organs, protecting them from mechanical shock and maintaining optimum body temperature. Likely, it improves palatability of feeds for all class of animals. Even in case of poultry, where taste is not a measurable factor, additional fat tends to reduce dustiness of feed and to overcome problems associated with acceptability of feed particles that are too fine. The skin has a rough, flaky appearance and its increased permeability leads to enhance water loss and consequently greater water consumption. The birds also have a decreased resistance to disease, a poorer efficiency of feed utilization and faulty feathering.

Fatty acids arising from digestion of dietary fats form insoluble calcium soaps which are assimilated with difficulty (Singh and Panda). However, a small amount of fat in the diet favors the absorption of calcium. A great excess of either calcium or phosphorus interferes with the absorption of the other. Therefore, a certain ratio between them in the diet is desirable for their optimum absorption. Vitamin D that is found in fats and oil increases the absorption of calcium and phosphorus especially if they are not present in the proper ratio (Singh and Panda, 1996). The bones of deficient animals are significantly demineralized and ash as well as calcium contents of the bones are reduced to about one-half level of the normal. Therefore, the present study was designed to determine whether the individual or interaction effects are observed during the experiment.

\section{Materials and Methods}

A study to investigate the effects of inclusion of different levels of soybean oil and sources of bone meal in the diet of broiler chicken was conducted. For this purpose, two hundred and seventy, eight day old, unsexed Vencobb-100 broiler chicks were obtained from commercial hatchery and reared in 27 different floor pens having $3.2 \mathrm{~m}^{2}$ sized. Each of nine treatments were organized by the interactions of two factors i.e. three levels $(0 \%, 2 \%$ and $4 \%)$ of soybean oil and three sources (GBM, PBM and IBM) of commercial bone meal were replicated three times with 10 chicks per pen and managed in $3 \times 3$ two factorial completely randomized design. Two types of rations, broiler starter ( 0 to $4^{\text {th }}$ weeks) and finisher $\left(5^{\text {th }}\right.$ to $7^{\text {th }}$ weeks) were fed. Broiler diets were isocaloric (3000 M.E Kcal $/ \mathrm{kg}$ ) however crude protein content was 20 and $19 \%$ for starter and finisher diets respectively. Each diet was adequately fortified with the required vitamins, mineral premixes and chlortetracycline was also mixed in the ration @ 500 gm/ton. The birds were fed ad libitum in all treatments up to the 6 weeks of age. The birds were vaccinated as per vaccination schedule. The different parameters during experiment such as body weight, weight gain, feed consumption, feed efficiency, carcass characteristics (dressing percentage and sharing of different organs) and the calcium, phosphorus and ash of blood and bone of broilers were measured. Subsequent trial on digestibility study was conducted at the end of the experimental periods for each replication and treatments groups. For determining nutrients digestibility, one bird was randomly selected from each treatment and were kept in cage. Before putting the birds in digestion trial, they were fasted for 24 hours. Thereafter they were fed ad libitum for 72 hours. Feed refusal were recorded and subjected to the proximate analysis according to the method described by National Research Council (NRC, 1984) and Association of Official Analytical Chemists (AOAC, 2001) . Likely, the calcium, phosphorus and ash of blood and bone of broilers were determined by the method as stated by AOAC (2001). The data were first tabulated in Microsoft Excel and statistically analyzed in $3 \times 3$ two factorial completely randomized design (CRD) using MSTAT-C computer software packages. Means were separated by using Least Significant Difference (LSD) at 5\% level of significance.

\section{Results and Discussions}

\section{Digestibility Coefficient}

The digestibility coefficients of CP, CF, EE, NFE and TA content of broiler finisher diet is presented in Table 1. Results showed that highly significant difference $(\mathrm{P}<0.01)$ in the digestibility coefficient of CP, NFE, CF, EE and TA among treatments.

The digestibility coefficient of $\mathrm{CP}$ was observed significantly $(\mathrm{P}<0.01)$ higher in treatment $\mathrm{T}_{3}$ compared to $\mathrm{T}_{1}$ and $\mathrm{T}_{7}$ and no significant differences existed among the rest of the treatments. The maximum digestibility coefficient of $\mathrm{CP}$ was recorded on $\mathrm{T}_{3}(85.80 \%)$ while minimum was recorded on $\mathrm{T}_{7}(83.20 \%)$. The digestibility coefficient of EE was observed significantly $(\mathrm{P}<0.01)$ higher in treatments $\mathrm{T}_{3}$ than that of $\mathrm{T}_{1}, \mathrm{~T}_{2}, \mathrm{~T}_{4}$ and $\mathrm{T}_{8}$. The maximum digestibility coefficient of $\mathrm{EE}$ was recorded on $\mathrm{T}_{3}(86.50 \%)$ while minimum was recorded on $\mathrm{T}_{1}(79.00 \%)$.

The digestibility coefficient of NFE was observed significantly $(\mathrm{P}<0.01)$ higher in treatment $\mathrm{T}_{2}$ than all treatments except treatments $\mathrm{T}_{1}$ and $\mathrm{T}_{4}$. The maximum digestibility coefficient of NFE was recorded on $\mathrm{T}_{3}$ $(80.80 \%)$ and minimum on $\mathrm{T}_{7}(77.70 \%)$. Likewise, the digestibility coefficient of TA was observed highly significant $(\mathrm{P}<0.01)$. The maximum digestibility coefficient of TA was recorded on $\mathrm{T}_{1}(43.00 \%)$ while minimum was recorded in $\mathrm{T}_{7}(33.60 \%)$. 
Table 1: Digestibility coefficient of nutrients of broilers fed finisher diets

\begin{tabular}{|c|c|c|c|c|c|c|}
\hline \multirow{2}{*}{ Treatments } & \multicolumn{6}{|c|}{ Digestibility coefficients $(\%)$ of } \\
\hline & DM & $\mathbf{C P}$ & CF & $\mathbf{E E}$ & NFE & Ash \\
\hline $\mathrm{T}_{1}=$ diet without soybean oil $+\mathrm{GBM}$ & 80.50 & $83.30^{\mathrm{b}}$ & 63.40 & $79.00^{\mathrm{d}}$ & $79.50^{\mathrm{bc}}$ & $43.00^{\mathrm{a}}$ \\
\hline $\mathrm{T}_{2}=$ diet with $2 \%$ soybean oil $+\mathrm{GBM}$ & 80.10 & $84.60^{\mathrm{ab}}$ & 64.00 & $83.50^{\mathrm{c}}$ & $80.80^{\mathrm{a}}$ & $42.50^{\mathrm{b}}$ \\
\hline $\mathrm{T}_{3}=$ diet with $4 \%$ soybean oil $+\mathrm{GBM}$ & 80.50 & $85.80^{\mathrm{a}}$ & 63.50 & $86.50^{\mathrm{a}}$ & $80.20^{\mathrm{ab}}$ & $42.70^{\mathrm{ab}}$ \\
\hline $\mathrm{T}_{4}=$ diet without soybean oil $+\mathrm{PBM}$ & 80.40 & $83.80^{\mathrm{b}}$ & 62.90 & $79.50^{\mathrm{d}}$ & $77.80^{\mathrm{d}}$ & $35.60^{c}$ \\
\hline $\mathrm{T}_{5}=$ diet with $2 \%$ soybean oil $+\mathrm{PBM}$ & 80.20 & $84.80^{\mathrm{ab}}$ & 63.00 & $83.43^{c}$ & $78.20^{\mathrm{d}}$ & $33.90^{\mathrm{d}}$ \\
\hline $\mathrm{T}_{6}=$ diet with $4 \%$ soybean oil $+\mathrm{PBM}$ & 80.10 & $84.80^{\mathrm{ab}}$ & 63.00 & $84.60^{\mathrm{bc}}$ & $78.90^{\text {cd }}$ & $34.10^{c}$ \\
\hline $\mathrm{T}_{7}=$ diet without soybean oil $+\mathrm{IBM}$ & 80.50 & $83.20^{\mathrm{b}}$ & 64.10 & $79.80^{\mathrm{d}}$ & $77.70^{\mathrm{d}}$ & $33.60^{\mathrm{d}}$ \\
\hline $\mathrm{T}_{8}=$ diet with $2 \%$ soybean oil $+\mathrm{IBM}$ & 80.20 & $84.80^{\mathrm{ab}}$ & 64.10 & $83.50^{c}$ & $77.90^{\mathrm{d}}$ & $33.80^{\mathrm{d}}$ \\
\hline $\mathrm{T}_{9}=$ diet with $4 \%$ soybean oil + IBM & 80.40 & $85.20^{\mathrm{ab}}$ & 64.00 & $85.50^{\mathrm{ab}}$ & $78.83^{\mathrm{cd}}$ & $34.03^{\mathrm{cd}}$ \\
\hline Mean & 80.32 & 84.47 & 63.55 & 82.81 & 78.87 & 37.02 \\
\hline Probability & Ns & 0.01 & Ns & 0.01 & 0.00 & 0.00 \\
\hline $\mathrm{CV} \%$ & 0.28 & 1.24 & 0.30 & 0.74 & 0.27 & 2.61 \\
\hline SEm & 0.05 & 1.08 & 0.37 & 0.37 & 0.44 & 1.33 \\
\hline LSD value & - & 2.45 & - & 1.43 & 1.08 & 1.22 \\
\hline
\end{tabular}

(Note: $\mathrm{GBM}=\mathrm{G}$ bone meal source, $\mathrm{PBM}=\mathrm{P}$ bone meal source, $\mathrm{IBM}=\mathrm{I}$ bone meal source)

Table 2: Average weekly feed consumption of broilers fed diets supplemented with different levels of soybean oil

\begin{tabular}{llllllll}
\hline \multirow{2}{*}{ Treatments } & \multicolumn{7}{c}{ Weeks } \\
\cline { 2 - 7 } & $\mathbf{1}^{\text {st }}$ & $\mathbf{2}^{\text {nd }}$ & $\mathbf{3}^{\text {rd }}$ & $\mathbf{4}^{\text {th }}$ & $\mathbf{5}^{\text {th }}$ & $\mathbf{6}^{\text {th }}$ & $\mathbf{7}^{\text {th }}$ \\
\hline $\mathrm{T}_{1}=$ diet without soybean oil & $87.44^{\mathrm{b}}$ & $209.82^{\mathrm{c}}$ & $349.53^{\mathrm{b}}$ & $573.00^{\mathrm{c}}$ & $937.48^{\mathrm{b}}$ & $981.83^{\mathrm{b}}$ & $1001.22^{\mathrm{b}}$ \\
$\mathrm{T}_{2}=$ diet with 2\% soybean oil & $88.97^{\mathrm{ab}}$ & $237.61^{\mathrm{b}}$ & $365.58^{\mathrm{b}}$ & $631.25^{\mathrm{b}}$ & $911.41^{\mathrm{b}}$ & $1018.37^{\mathrm{a}}$ & $1319.33^{\mathrm{a}}$ \\
$\mathrm{T}_{3}=$ diet with 4\% soybean oil & $92.85^{\mathrm{a}}$ & $253.21^{\mathrm{a}}$ & $401.53^{\mathrm{a}}$ & $693.66^{\mathrm{a}}$ & $1013.87^{\mathrm{a}}$ & $1098.76^{\mathrm{a}}$ & $1488.16^{\mathrm{a}}$ \\
\hline Mean & 89.75 & 233.55 & 372.21 & 632.64 & 954.25 & 1032.99 & 1269.57 \\
Probability & 0.01 & 0.01 & 0.01 & 0.01 & 0.01 & 0.05 & 0.01 \\
CV \% & 3.11 & 9.41 & 7.15 & 9.54 & 5.58 & 5.79 & 19.48 \\
SEm & 1.10 & 1.60 & 6.64 & 6.36 & 14.17 & 44.51 & 56.07 \\
LSD value & 4.51 & 6.51 & 27.04 & 25.89 & 57.70 & 181.2 & 228.3 \\
\hline
\end{tabular}

On the whole, maximum digestibility coefficient of different nutrient was observed in $\mathrm{T}_{3}$ where the combination of $4 \%$ soybean oil and GBM might have helped in increasing the coefficient of digestibility of nutrients.

Chicks fed diets with soybean oil have shown higher apparent digestibility values of ether extract than the ones that received rations without soybean oil during the first three weeks of age (Cancado, 1999).

\section{Feed Consumption}

The mean weekly feed consumption of broilers at different levels of soybean oil is presented in Table 2.

The analysis of variance (ANOVA) indicated that the effect of soybean oil on the variation of the weekly feed consumption of broiler was observed highly significant $(\mathrm{P}<0.01)$ during first, second, third, fourth, fifth and seventh week and significant $(\mathrm{P}<0.05)$ only during sixth week. 
Significantly $(\mathrm{P}<0.01)$ higher feed consumption $(92.85 \mathrm{gm})$ of broiler was obtained on basal diet with $4 \%$ soybean oil followed by basal diet with $2 \%$ soybean oil $(88.97 \mathrm{gm})$ and without soybean oil $(87.44 \mathrm{gm})$ in first week.

Similarly in the seventh week, significantly $(\mathrm{P}<0.01)$ higher feed consumption (1488.16 gm) of broiler was recorded on basal diet with $4 \%$ soybean oil followed by $2 \%$ soybean oil (1319.33 gm) and without soybean oil (1001.22 gm).

The highest feed consumption (1488.16 gm) was recorded in broilers on the diet with $4 \%$ soybean oil in seventh week. Results indicated that the diet with $4 \%$ soybean oil and $2 \%$ soybean oil in broilers increased the feed intake. The previous study reported feed consumption was increased in broilers by feeding soybean oil and therefore they are agreed with the similar results (Griffiths et al., 1997; Rath et al., 2000).

\section{Body Weight}

The average initial and cumulative body weight of broilers at different levels of soybean oil is presented in Table 3 and 4.

The analysis of variance (ANOVA) indicated that the effect of soybean oil on the variation of the weekly cumulative body weight of broiler was observed non-significant $(\mathrm{P}>0.05)$ in first week of feeding. Significantly $(\mathrm{P}<0.01)$ higher cumulative body weight (319.89 gm) of broiler was obtained on the diet with $4 \%$ soybean oil followed by $2 \%$ soybean oil (309.22 gm) and without soybean oil (295.22 $\mathrm{gm})$ in second week.
In third week, significantly $(\mathrm{P}<0.01)$ higher cumulative body weight (536.88 gm) of broilers was recorded on the diet with $4 \%$ soybean oil followed by $2 \%$ soybean oil (518.44 gm) and without soybean oil (501.77 gm). Similarly, significantly $(\mathrm{P}<0.01)$ higher cumulative body weight ( $894.66 \mathrm{gm}$ ) of broiler was recorded on the diet with $4 \%$ soybean oil followed by $2 \%$ soybean oil $(855.88 \mathrm{gm})$ and without soybean oil $(814.11 \mathrm{gm})$ in fourth week. In fifth week, significantly $(\mathrm{P}<0.01)$ higher cumulative body weight $(1327.77 \mathrm{gm})$ of broiler was recorded with basal diet with $4 \%$ soybean oil followed by no soybean oil (1266.66 gm) and 2\% soybean oil (1264.44 gm).

In sixth week, significantly $(\mathrm{P}<0.01)$ higher cumulative body weight (1756.66 gm) of broiler was recorded with basal diet with $4 \%$ soybean oil. But cumulative body weight of broiler with basal diet containing $2 \%$ soybean oil and without soybean oil were same (1672.22 gm).

In seventh week, significantly $(\mathrm{P}<0.01)$ higher cumulative body weight (2157.22 gm) of broiler was recorded on the diet containing $4 \%$ soybean oil followed by basal diet with $2 \%$ soybean oil (2033.88 $\mathrm{gm})$ and without soybean oil (1948.88 gm).

Significantly $(\mathrm{P}<0.01)$ the highest cumulative body weight of broilers was recorded with the basal diet containing $4 \%$ soybean oil. Female broilers fed with rations containing different sources of lipids (beef tallow, soybean oil, canola oil, marine fish oil or a mixture of these oils) and observed that live weight was significantly higher when soybean oil was used, that was similar to the experimental results (Shafey, 1993).

Table 3: Average cumulative body weight of broilers fed diets supplemented with different levels of soybean oil

\begin{tabular}{|c|c|c|c|c|c|c|c|}
\hline \multirow{2}{*}{ Treatments } & \multicolumn{7}{|c|}{ Weeks } \\
\hline & $\overline{1^{\text {st }}}$ & $2^{\text {nd }}$ & $3^{\text {rd }}$ & $4^{\text {th }}$ & $5^{\text {th }}$ & $6^{\text {th }}$ & $7^{\text {th }}$ \\
\hline $\mathrm{T}_{1}=$ diet without soybean oil & 116.22 & $295.22^{c}$ & $501.77^{c}$ & $814.11^{\mathrm{c}}$ & $1266.66^{b}$ & $1672.22^{b}$ & $1948.88^{c}$ \\
\hline $\mathrm{T}_{2}=$ diet with $2 \%$ soybean oil & 114.44 & $309.22^{\mathrm{b}}$ & $518.44^{b}$ & $855.88^{b}$ & $1264.44^{b}$ & $1672.22^{b}$ & $2033.88^{b}$ \\
\hline $\mathrm{T}_{3}=$ diet with $4 \%$ soybean oil & 115.55 & $319.22^{\mathrm{a}}$ & $536.88^{\mathrm{a}}$ & $894.66^{\mathrm{a}}$ & $1327.77^{\mathrm{a}}$ & $1756.66^{\mathrm{a}}$ & $2157.22^{\mathrm{a}}$ \\
\hline Mean & 115.40 & 307.89 & 519.03 & 854.88 & 1286.29 & 1700.37 & 2046.66 \\
\hline Probability & 0.25 & 0.01 & 0.01 & 0.01 & 0.01 & 0.01 & 0.01 \\
\hline $\mathrm{CV} \%$ & 0.78 & 3.92 & 3.38 & 4.71 & 2.79 & 2.87 & 5.12 \\
\hline SEm & 0.52 & 6.96 & 10.14 & 23.26 & 20.75 & 28.15 & 60.48 \\
\hline LSD value & - & 6.46 & 9.19 & 11.19 & 49.75 & 73.44 & 36.18 \\
\hline
\end{tabular}


Table 4: Average cumulative body weight of broilers fed diets supplemented with different levels of soybean oil and different sources of bone meal

\begin{tabular}{|c|c|c|c|c|c|c|c|}
\hline \multirow{2}{*}{ Treatments } & \multicolumn{7}{|c|}{ Weeks } \\
\hline & $\overline{1^{\text {st }}}$ & $2^{\text {nd }}$ & $3^{\text {rd }}$ & $4^{\text {th }}$ & $5^{\text {th }}$ & $6^{\text {th }}$ & $7^{\text {th }}$ \\
\hline $\mathrm{T}_{1}=$ diet without soybean oil $+\mathrm{GBM}$ & 116.00 & 294.0 & 501.33 & 3810.00 & 1263.33 & 31683.33 & 31930.00 \\
\hline $\mathrm{T}_{2}=$ diet with $2 \%$ soybean oil $+\mathrm{GBM}$ & 114.33 & 308.0 & 517.33 & 3850.00 & 1286.66 & 51666.66 & 62008.33 \\
\hline $\mathrm{T}_{3}=$ diet with $4 \%$ soybean oil $+\mathrm{GBM}$ & 115.00 & 318.0 & 532.66 & 6893.00 & 1306.66 & 1750.00 & 02156.66 \\
\hline $\mathrm{T}_{4}=$ diet without soybean oil $+\mathrm{PBM}$ & 117.33 & 296.6 & 502.66 & 6813.66 & 1283.33 & 1666.66 & 61966.66 \\
\hline $\mathrm{T}_{5}=$ diet with $2 \%$ soybean oil $+\mathrm{PBM}$ & 114.66 & 311.6 & 522.00 & 0857.66 & 1243.33 & 1666.66 & 62030.00 \\
\hline $\mathrm{T}_{6}=$ diet with $4 \%$ soybean oil $+\mathrm{PBM}$ & 117.00 & 320.6 & 536.66 & 6896.00 & 1333.33 & 1766.66 & 62168.33 \\
\hline $\mathrm{T}_{7}=$ diet without soybean oil $+\mathrm{IBM}$ & 115.33 & 295.0 & 501.33 & 3818.66 & 1253.33 & 1666.66 & 61950.00 \\
\hline $\mathrm{T}_{8}=$ diet with $2 \%$ soybean oil $+\mathrm{IBM}$ & 114.33 & 308.0 & 516.00 & 0860.00 & 1263.33 & 1683.33 & 32063.33 \\
\hline $\mathrm{T}_{9}=$ diet with $4 \%$ soybean oil + IBM & 114.66 & 319.0 & 541.33 & 3895.00 & 1343.33 & 1753.33 & 32146.66 \\
\hline Mean & 115.40 & 307.8 & 519.03 & 3854.89 & 1286.29 & 1700.37 & 72046.66 \\
\hline Probability & - & - & - & - & 0.35 & - & 0.24 \\
\hline $\mathrm{CV} \%$ & 0.98 & 3.42 & 2.98 & 4.10 & 2.73 & 2.53 & 4.51 \\
\hline SEm & 0.38 & 3.51 & 5.15 & 11.69 & 11.71 & 14.33 & 30.80 \\
\hline
\end{tabular}

\section{Body Weight Gain}

The average weekly body weight gain of broilers fed with soybean oil is presented in Table 5.

The analysis of variance (ANOVA) indicated that the effect of soybean oil on the variation of body weight gain of broilers was observed highly significant $(\mathrm{P}<0.01)$ during second, fourth, fifth and seventh week and non-significant ( $\mathrm{P}>0.05)$ during first, third and sixth week.

In second week, significantly $(\mathrm{P}<0.01)$ higher body weight gain (203.66 gm) was obtained with the diet containing $4 \%$ soybean oil followed by basal diet with $2 \%$ soybean oil (194.77 gm) and without soybean oil (179.00 gm). Significantly $(\mathrm{P}<0.01)$ higher body weight gain $(357.77 \mathrm{gm})$ of broilers was recorded with the diet containing $4 \%$ soybean oil followed by the diet with $2 \%$ soybean oil (337.44 gm) and without soybean oil (312.33 gm) during fourth week.

In fifth week, significantly $(\mathrm{P}<0.01)$ higher body weight gain (431.77 gm) of broiler was recorded in basal diet with $4 \%$ soybean oil followed by the diet with $2 \%$ soybean oil
(399.66 gm) and without soybean oil (352.55 gm). Likewise, significantly $(\mathrm{P}<0.01)$ higher body weight gain (395.00 gm) of broilers was obtained with the diet with $4 \%$ soybean oil followed by basal diet with $2 \%$ soybean oil (361.66 gm) and without soybean oil (293.33 gm) in seventh week.

Significantly $(\mathrm{P}<0.01)$ the highest body weight gain was due to the best response of given level of supplementation of soybean oil. The previous studies reported that the body weight and weight gain through seventh weeks of age were improved by substituting the fat in the diets [9]. They evaluated broiler rations containing 0,4 and $8 \%$ of soybean oil and observed similar weight gain between the different lipidic levels in birds fed with soybean oil in comparison to the birds fed without soybean oil which is similar to these results.

Significantly $(\mathrm{P}<0.05)$ the highest body weight gain was due to the best response of $4 \%$ soybean oil. Previous works were also described the similar results (Atteh et al., 1983; Corino et al., 1980). 
Table 5: Average body weight gain of broilers fed diets supplemented with different levels of soybean oil

\begin{tabular}{|c|c|c|c|c|c|c|c|}
\hline \multirow{2}{*}{ Treatments } & \multicolumn{7}{|c|}{ Weeks } \\
\hline & $\mathbf{1}^{\text {st }}$ & $2^{\text {nd }}$ & $3^{\text {rd }}$ & $4^{\text {th }}$ & $5^{\text {th }}$ & $6^{\text {th }}$ & $7^{\text {th }}$ \\
\hline $\mathrm{T}_{1}=$ diet without soybean oil & 72.67 & $179.00^{c}$ & 206.55 & $312.33^{c}$ & $352.55^{\mathrm{c}}$ & 405.55 & $293.33^{b}$ \\
\hline $\mathrm{T}_{2}=$ diet with $2 \%$ soybean oil & 70.35 & $194.77^{b}$ & 209.22 & $337.44^{b}$ & $399.66^{b}$ & 407.77 & $361.66^{\mathrm{a}}$ \\
\hline $\mathrm{T}_{3}=$ diet with $4 \%$ soybean oil & 72.11 & $203.66^{\mathrm{a}}$ & 217.66 & $357.77^{\mathrm{a}}$ & $431.77^{\mathrm{a}}$ & 424.44 & $395.00^{\mathrm{a}}$ \\
\hline Mean & 71.71 & 192.48 & 211.14 & 335.85 & 427.99 & 412.59 & 350.00 \\
\hline Probability & 0.13 & 0.01 & 0.06 & 0.01 & 0.01 & - & 0.01 \\
\hline $\mathrm{CV} \%$ & 1.69 & 6.49 & 2.75 & 6.78 & 6.23 & 2.50 & 14.81 \\
\hline SEm & 0.70 & 7.21 & 3.35 & 13.14 & 15.38 & 5.96 & 29.92 \\
\hline LSD value & - & 5.54 & - & 12.95 & 37.79 & - & 62.02 \\
\hline
\end{tabular}

Table 6: Average feed conversion ratio of broilers fed diets supplemented with different levels of soybean oil

\begin{tabular}{|c|c|c|c|c|c|c|c|}
\hline \multirow{2}{*}{ Treatments } & \multicolumn{7}{|c|}{ Weeks } \\
\hline & $\overline{1^{\text {st }}}$ & $2^{\text {nd }}$ & $3^{\text {rd }}$ & $4^{\text {th }}$ & $5^{\text {th }}$ & $6^{\text {th }}$ & $7^{\text {th }}$ \\
\hline $\mathrm{T}_{1}=$ diet without soybean oil & $1.20^{\mathrm{b}}$ & $1.17^{\mathrm{c}}$ & $1.69^{b}$ & $1.83^{b}$ & $2.07^{b}$ & $2.42^{b}$ & $3.41^{\mathrm{c}}$ \\
\hline $\mathrm{T}_{2}=$ diet with $2 \%$ soybean oil & $1.26^{\mathrm{a}}$ & $1.22^{\mathrm{b}}$ & $1.74^{\mathrm{b}}$ & $1.87^{\mathrm{b}}$ & $2.28^{\mathrm{a}}$ & $2.50^{\mathrm{b}}$ & $3.64^{\mathrm{b}}$ \\
\hline $\mathrm{T}_{3}=$ diet with $4 \%$ soybean oil & $1.28^{\mathrm{a}}$ & $1.24^{\mathrm{a}}$ & $1.84^{\mathrm{a}}$ & $1.93^{\mathrm{a}}$ & $2.35^{\mathrm{a}}$ & $2.59^{\mathrm{a}}$ & $3.76^{\mathrm{a}}$ \\
\hline Mean & 1.25 & 1.21 & 1.76 & 1.88 & 2.23 & 2.50 & 3.60 \\
\hline Probability & 0.01 & 0.01 & 0.01 & 0.01 & 0.01 & 0.01 & 0.01 \\
\hline $\mathrm{CV} \%$ & 3.34 & 2.98 & 4.35 & 2.68 & 6.52 & 3.40 & 4.94 \\
\hline SEm & 0.01 & 0.01 & 0.03 & 0.02 & 0.05 & 0.03 & 0.06 \\
\hline LSD value & 0.04 & 0.01 & 0.04 & 0.04 & 0.14 & 0.08 & 0.11 \\
\hline
\end{tabular}

\section{Feed Conversion Ratio}

The average weekly feed conversion ratio of broilers fed diets containing soybean oil is presented in Table 6.

The analysis of variance (ANOVA) indicated that the effect of levels of soybean oil on the variation of the weekly feed conversion ratio of broiler was observed highly significant $(\mathrm{P}<0.01)$ during first week to seventh week of experiment. Significantly $(\mathrm{P}<0.01)$ better feed conversion ratio was obtained with the diet containing without soybean oil (1.20) over $2 \%$ soybean oil (1.26) and $4 \%$ soybean oil (1.28) during first week. Likely, significantly $(\mathrm{P}<0.01)$ better feed conversion ratio was obtained with the basal diet containing without soybean oil (1.17) over the diet with $2 \%$ soybean oil (1.22) and 4\% soybean oil (1.24) in second week.
During third week, significantly $(\mathrm{P}<0.01)$ better feed conversion ratio(1.69) was obtained with the basal diet containing without soybean oil over the basal diet with $2 \%$ soybean oil (1.74) and 4\% soybean oil (1.84). Significantly $(\mathrm{P}<0.01)$ better feed conversion ratio $(1.83)$ was obtained on the diet without soybean oil over the diet with $2 \%$ soybean oil (1.87) and $4 \%$ soybean oil (1.93) during the fourth week.

During the fifth week, significantly $(\mathrm{P}<0.01)$ better feed conversion ratio (2.07) was recorded on the diet without soybean oil over the diet with $2 \%$ soybean oil (2.28) and $4 \%$ soybean oil (2.35). Similarly, significantly $(\mathrm{P}<0.01)$ better feed conversion ratio (2.42) was recorded on the diet without soybean oil over the diet with $2 \%$ soybean oil (2.50) and $4 \%$ soybean oil (2.59) during sixth week. 
In seventh week, significantly $(\mathrm{P}<0.01)$ better feed conversion ratio (3.41) was recorded on the diet without soybean oil over the diet with $2 \%$ soybean oil (3.64) and $4 \%$ soybean oil (3.76). Significantly $(\mathrm{P}<0.01)$ the better feed conversion ratio was recorded on the diet without soybean oil than the diet containing any level of soybean oil. It might be due to the average weekly feed intake was greater as compared to the average body weight gain of the broiler fed diet with soybean oil. Weight gain, feed intake and feed conversion of broilers fed with diets containing $4 \%$ of poultry fat, $4 \%$ of soybean oil or a mixture of $2 \%$ of soybean oil and $2 \%$ of poultry fat were not affected by oil sources. However, there was a decrease in feed intake and weight when the mixture was used.

\section{Carcass Characteristics}

The carcass traits of broilers supplemented with different levels of soybean oil and sources of bone meal in different treatments is presented in Table 7.
The maximum weight of blood $(2.44 \%)$ was observed on $\mathrm{T}_{6}$ and minimum $(2.17 \%)$ on $\mathrm{T}_{1}$. The maximum feather weight was observed of $\mathrm{T}_{9}(5.97 \%)$ and lowest on $\mathrm{T}_{4}(5.12 \%)$. Dressed carcass weight was found maximum $(92.67 \%)$ on $\mathrm{T}_{4}$ and minimum on $\mathrm{T}_{9}(91.62 \%)$. The maximum visceral weight $(15.65 \%)$ was recorded on $\mathrm{T}_{6}$ and minimum on $\mathrm{T}_{1}$ $(14.50 \%)$. The maximum intestine weight $(8.11 \%)$ was observed on $\mathrm{T}_{9}$ and minimum $(7.58 \%)$ on $\mathrm{T}_{1}$. The leg weight was found maximum $(4.92 \%)$ on $\mathrm{T}_{4}$ and minimum on $\mathrm{T}_{1}$ $(4.22 \%)$. The maximum liver weight $(2.87 \%)$ was observed on $\mathrm{T}_{6}$ and minimum on $\mathrm{T}_{8}(2.23 \%)$. The maximum heart weight $(0.51 \%)$ was recorded on $\mathrm{T}_{1}$ and minimum on $\mathrm{T}_{5}$ $(0.44 \%)$. The maximum gizzard weight $(3.99 \%)$ was found on $\mathrm{T}_{6}$ and minimum on $\mathrm{T}_{3}$ (3.48). But the empty gizzard weight was found maximum $(2.97 \%)$ on $\mathrm{T}_{9}$ and minimum $(2.18 \%)$ on $\mathrm{T}_{6}$.

Table 7: Slaughter characteristics of broiler fed diets supplemented with different levels of soybean oil and sources of bone meal

\begin{tabular}{|c|c|c|c|c|c|c|c|}
\hline Treatments & $\begin{array}{l}\text { Live wt. } \\
\text { (gm) }\end{array}$ & $\begin{array}{l}\text { Blood } \\
\text { wt. \% }\end{array}$ & $\begin{array}{l}\text { Feather } \\
\text { wt. } \%\end{array}$ & $\begin{array}{l}\text { Dressed carcass } \\
\text { wt. } \%\end{array}$ & $\begin{array}{l}\text { Visceral } \\
\text { wt. } \%\end{array}$ & $\begin{array}{l}\text { Abdominal fat } \\
\text { wt. } \%\end{array}$ & $\begin{array}{l}\text { Dressing } \\
\text { percent }\end{array}$ \\
\hline $\begin{array}{l}\mathrm{T}_{1}=\text { diet without soybean } \\
\text { oil + GBM }\end{array}$ & 1930.00 & 2.17 & 5.36 & 92.47 & 14.50 & 1.09 & 73.11 \\
\hline $\begin{array}{l}\mathrm{T}_{2}=\text { diet with } 2 \% \\
\text { soybean oil }+\mathrm{GBM}\end{array}$ & 2008.33 & 2.26 & 5.34 & 92.40 & 15.27 & 1.97 & 74.41 \\
\hline $\begin{array}{l}\mathrm{T}_{3}=\text { diet with } 4 \% \\
\text { soybean oil + GBM }\end{array}$ & 2156.66 & 2.42 & 5.49 & 92.09 & 14.94 & 2.38 & 74.94 \\
\hline $\begin{array}{l}\mathrm{T}_{4}=\text { diet without soybean } \\
\text { oil + PBM }\end{array}$ & 1966.66 & 2.21 & 5.12 & 92.67 & 14.96 & 1.08 & 73.38 \\
\hline $\begin{array}{l}\mathrm{T}_{5}=\text { diet with } 2 \% \\
\text { soybean oil + PBM }\end{array}$ & 2030.00 & 2.28 & 5.19 & 92.53 & 15.34 & 1.49 & 73.43 \\
\hline $\begin{array}{l}\mathrm{T}_{6}=\text { diet with } 4 \% \\
\text { soybean oil + PBM }\end{array}$ & 2168.33 & 2.44 & 5.26 & 92.30 & 15.65 & 2.34 & 74.86 \\
\hline $\begin{array}{l}\mathrm{T}_{7}=\text { diet without soybean } \\
\text { oil + IBM }\end{array}$ & 1950.00 & 2.19 & 5.21 & 92.60 & 15.51 & 1.04 & 73.27 \\
\hline $\begin{array}{l}\mathrm{T}_{8}=\text { diet with } 2 \% \\
\text { soybean oil + IBM }\end{array}$ & 2063.33 & 2.32 & 5.89 & 91.79 & 14.83 & 1.39 & 73.17 \\
\hline $\begin{array}{l}\mathrm{T}_{9}=\text { diet with } 4 \% \\
\text { soybean oil + IBM }\end{array}$ & 2146.66 & 2.41 & 5.97 & 91.62 & 15.19 & 2.36 & 74.85 \\
\hline Mean & 2046.66 & 2.30 & 5.43 & 92.27 & 15.13 & 1.68 & 73.93 \\
\hline Probability & 92.39 & 0.10 & 0.31 & 0.37 & 0.36 & 0.58 & 1.70 \\
\hline $\mathrm{CV} \%$ & 4.51 & 4.35 & 5.71 & 0.40 & 2.38 & 34.60 & 2.30 \\
\hline SEm & 30.80 & 0.03 & 0.10 & 0.12 & 0.12 & 0.19 & 0.57 \\
\hline
\end{tabular}


The maximum abdominal fat percentage (2.38\%) was recorded on $\mathrm{T}_{3}$ and minimum on $\mathrm{T}_{7}(1.04 \%)$. The maximum abdominal fat percentage on $\mathrm{T}_{3}$ might be due to the feeding of the diet containing $4 \%$ soybean oil. The previous works were reported that feeding $2 \%$ and $4 \%$ soybean oil increased the abdominal fat content (Zollitsch et al., 1997). They found that there were no significant differences between fats with respect to DM, protein and fat content of thigh meat, or organoleptic traits of breast meat. But the composition of the abdominal fat was typically influenced by dietary fat sources the content of polyunsaturated fatty acids was significantly elevated in soybean oil (Zollitsch et al., 1997). But the dressing percentage was recorded maximum on $\mathrm{T}_{3}(74.94 \%)$ and minimum on $\mathrm{T}_{1}(73.11 \%)$.

\section{Calcium, Phosphorus and Ash Deposition in Tibia Bone and Blood}

The Ash, calcium and phosphorus content of blood and bone tibia of experimental broiler is presented in Table 8 .

The maximum ash content $(5.87 \%)$ on blood was recorded on $\mathrm{T}_{2}$ and $\mathrm{T}_{3}$ and minimum $(5.66 \%)$ on $\mathrm{T}_{4}$. The calcium percentage was maximum on $\mathrm{T}_{3}(21.26 \%)$ and minimum on $\mathrm{T}_{5}(18.71 \%)$ on blood. However, the phosphorus percentage was maximum $(12.57 \%)$ on $\mathrm{T}_{3}$ and minimum $(10.48 \%)$ on $\mathrm{T}_{4}$ in blood. Similarly, the tibia bone ash was maximum $(8.13 \%)$ on $\mathrm{T}_{2}$ and minimum $(7.91 \%)$ on $\mathrm{T}_{5}$. Similar trend for tibia bone calcium was recorded as in tibia bone ash percentage. The tibia bone phosphorus content was maximum (14.67\%) on $\mathrm{T}_{3}$ and minimum $(12.83 \%)$ on $\mathrm{T}_{8}$.

The results indicated that the basal diet with soybean oil containing GBM increased the calcium and phosphorus content of blood and tibia bone. It is due to the bone calcification and mineralization in the influence of the soybean oil with the GBM. The previous works also reported that the ash calcium and phosphorus content was affected by the interaction effect of soybean oil and bone meal (Matterson et al., 1945). It was suggested that adequate calcium and phosphorus levels are needed throughout the rearing period because of the continuous and rapid rate of bone growth.

The bioavailability of calcium from different calcium and phosphorus sources for the chick were estimated and concluded that there were significant differences in the calcium availability of feed grade phosphates to the chicks and suggested a positive correlation between the availability of calcium and phosphorus in feed grade supplements (Dilworth and Day, 1964). However, calcium utilization of bone meal, oyster shell and limestone by the chick was dependent upon the particle size of the supplements (McNaughton et al., 1974).

Table 8: Interaction effects on ash, calcium and phosphorus content of blood and tibia bone of broilers fed diets supplemented with different levels of soybean oil and sources of bone meal

\begin{tabular}{lllllll}
\hline Treatments & \multicolumn{3}{l}{ Blood content } & \multicolumn{3}{c}{ Tibia bone content } \\
\cline { 2 - 7 } & Ash, \% Calcium, \% & Ash, \% Calcium, \% & Ash, \% Calcium, \% \\
\hline $\mathrm{T}_{1}=$ diet without soybean oil + GBM & 5.73 & 20.84 & 5.73 & 20.84 & 5.73 & 20.84 \\
$\mathrm{~T}_{2}=$ diet with 2\% soybean oil + GBM & 5.87 & 20.95 & 5.87 & 20.95 & 5.87 & 20.95 \\
$\mathrm{~T}_{3}=$ diet with 4\% soybean oil + GBM & 5.87 & 21.26 & 5.87 & 21.26 & 5.87 & 21.26 \\
$\mathrm{~T}_{4}=$ diet without soybean oil + PBM & 5.66 & 18.79 & 5.66 & 18.79 & 5.66 & 18.79 \\
$\mathrm{~T}_{5}=$ diet with 2\% soybean oil + PBM & 5.71 & 18.71 & 5.71 & 18.71 & 5.71 & 18.71 \\
$\mathrm{~T}_{6}=$ diet with 4\% soybean oil + PBM & 5.73 & 18.89 & 5.73 & 18.89 & 5.73 & 18.89 \\
$\mathrm{~T}_{7}=$ diet without soybean oil + IBM & 5.84 & 19.44 & 5.84 & 19.44 & 5.84 & 19.44 \\
$\mathrm{~T}_{8}=$ diet with 2\% soybean oil + IBM & 5.73 & 19.58 & 5.73 & 19.58 & 5.73 & 19.58 \\
$\mathrm{~T}_{9}=$ diet with 4\% soybean oil + IBM & 5.71 & 19.39 & 5.71 & 19.39 & 5.71 & 19.39 \\
\hline Mean & 5.76 & 19.76 & 5.76 & 19.76 & 5.76 & 19.76 \\
Probability & - & - & - & - & - & - \\
CV \% & 1.34 & 5.03 & 1.34 & 5.03 & 1.34 & 5.03 \\
SEm & 0.03 & 0.33 & 0.03 & 0.33 & 0.03 & 0.33
\end{tabular}

(Note: $\mathrm{GBM}=\mathrm{G}$ bone meal source, $\mathrm{PBM}=\mathrm{P}$ bone meal source, $\mathrm{IBM}=\mathrm{I}$ bone meal source) 


\section{Acknowledgement}

It is my privilege to avail of the opportunity and convey my sincere appreciation and gratitude to the chairman of the advisory committee Prof. Dr. Maheshwar Sapkota, the members of my advisory committee Prof. Dr. Jagat Lal Yadav, and Prof. Dr. Dainik Bahadur Nepali for their incessant encouragement, subtle remarks and candid suggestion in accomplishing this work. My sincere gratitude is extended to Prof. Dr. Durga Datta Dhakal and Prof. Dr. Sundar Man Shrestha for providing the favorable environment and technical assistance that allowed success to this piece of work. We would like to give our special thanks to Mrs. Geeta Jamarkattel Tiwari and Mr. Ramashish Shah for their continuous support and assistance on data management, statistical analysis, ANOVA and MSTAT-C computer software packages. I am also thankful to all members of my department, colleagues and my family for their encouragement and cordial help.

\section{References}

AOAC (2001) Association of Official Analytical Chemists. International Official Methods of Analysis. $17^{\text {th }}$ ed. Horwitz W. (ed.): AOAC Int., Arlington, USA.

Atteh JO, Leeson S and Julian RJ (1983) Effects of dietary levels and types of fat on performance and mineral metabolism of broiler chicks. Poult. Sci. 62(12): 2403-2411. DOI: 10.3382/ps.0622403

Cancado SV (1999) Efeito do jejum pre-alojamento de pintos de corte sobre o desempentho, orgaos digestos e digestibilidade da racao (tese). Belo Horizonte: Escola de Veterinaria, UFMG.

Corino C, Dellorto V and Pedron O (1980) Effects of acid composition of fats and oils on the nutritive efficiency of broiler feeds. Rev. Zootech. Vet. 2: 94-99.
Dilworth BC and Day EJ (1964) Phosphorus availability studies with feed grade phosphates. Poultry Sci. 43(4):1039-1044. DOI: $10.3382 /$ ps.0431039

Griffiths L, Leeson S and Summers JD (1997) Influence of energy system and level of various fat sources on performance and carcass composition of broilers. Poultry Sci. 56:10181026. DOI: $10.3382 /$ ps. 0561018

Klasing KC (1998) Comparative Avian Nutrition. Wallingford, Oxon: CABI Publishing,

Matterson LD, Singsen EP and Scott HM (1945) Rock phosphates as phosphorus supplements for the growing chick. Poult. Sci. 24:188-190. DOI: $10.3382 /$ ps.0240188

McNaughton JL, Dilworth BC and Day EJ (1974) Effect of particle size on the utilization of calcium supplements by the chick. Poult. Sci. 53(3):1024-1029. DOI: 10.3382/ps.0531024

NRC (1984) National Research Council. Nutrients Requirements of Poultry. $8^{\text {th }}$ ed.. National Academy of Sciences, Washington, D.C.

Rath NC, Huff GR, Huff WE and Balog JM (2000) Factors regulating bone maturity and strength in poultry. Poult. Sci. 79: 1024-1032. DOI: $10.1093 / \mathrm{ps} / 79.7 .1024$

Shafey TM (1993) Calcium tolerance of growing chickens: effect of ratio of dietary calcium to available phosphorus. World Poult. Sci. J. 49:5-18. Online publication: 01.09.2007. DOI: $10.1079 / W P S 19930002$

Singh KS and Panda B (1996) Poultry Nutrition. $3^{\text {rd }}$ ed. Kalyani Publishers 104-113.

Zollitsch W, Knaus W, Aichinger F and Lettner F (1997) Effects of different dietary fat sources on performance and carcass characteristics of broilers. Animal Feed Science and Technology 66(1): 63-73. DOI: 10.1016/S03778401(96)01126-1 